\title{
IPTEKS EDUKASI DALAM PENGAMATAN MELAKUKAN TRANSAKSI PERDAGANGAN KOMODITI BERJANGKA PADA PERUSAHAAN PIALANG PT. VICTORY INTERNATIONAL FUTURES
}

\author{
Sharon Cornelia Watupongoh ${ }^{1}$, Lady Diana Latjandu ${ }^{2}$ \\ 1,2Jurusan Akuntansi, Fakultas Ekonomi dan Bisnis, Universitas Sam Ratulangi, Jl. Kampus Bahu, Manado, \\ 95115, Indonesia \\ email : swatupongoh@ymail.com
}

\begin{abstract}
PT. Victory International Futures was established in 2003 as a brokerage company in the world financial market that uses information technology to support its business. Centered in the city of Surabaya in the heart of the Indonesian business city. PT. Victory International Futures is one of the institutions recognized by the Indonesian government. We provide 100\% focus on trading via the internet using the "Meta Trader 5" system PT. Victory International Futures is under the supervision of the Commodity Futures Trading (BAPPEBTI), Member of Indonesia Commodity \& Derivatives Exchanges (ICDX) / Indonesian Commodity and Derivative Exchange (BKDI) and PT. Identrust Security International (ISI). Time never stops in the era of global trade and so does PT. Victory International Futures serves thousands of customers directly and always provides quality and professional financial services.

Keywords : brokerage company, gold, forex, trading system via the internet
\end{abstract}

\section{PENDAHULUAN}

Tujuan utama perusahaan adalah salah satu perusahaan broker forex yang pelayanannya untuk nasabah dalam bidang investasi pada produk-produk seperti indeks futures,forex dan logam. Jenis platform trading online yang dimanfaatkan dengan jenis asset finansial yang diperdagangkan klien. Meta Trader 5 adalah aplikasi yang dilakukan nasabah untuk melakukan trading forex. Ada 2 teknik dalam teknik analisis yaitu strategi teknikal dan strategi fundamental. Kedua teknik tersebutmenebak secara pasti pergerakan harga dan membantu dalam pengambilan keputusan buy/sell. Analisis tersebut sudah sering digunakan para investor,masihadanya banyak kasus-kasus yang terjadi pada investor baru di dunia pasar berjangka. Contohnya investor yang tidak memperhitungkan ketahanan dana yangdia punya, padahal sebenarnya analisisnya sudah tepat. Untuk itu dalam dunia investasi kita mengenal isitilah "high risk,high return". Seorang trader setidaknya harus memahami dasar tentang manajemen modal, trading plan, psikologi trading, manejemen resiko dan money management. Jika seorang trader dapat menguasai salah satu teknik dasar pengambilan keputasan dalam trading, maka peluang untuk meraih kesuksesan pada jangka pendek/ jangka panjang terbuka lebar.

\section{TINJAUAN PUSTAKA}

Analisis Teknikal. Fama (1970) seorang ekonom,menerbitkan suatu tulisan yang dimuat pada Journal of Finance, mengatakan bahwa "Dalam masa singkat, bukti-bukti pendukung dari modal pasar yang tepat guna akan meluas dan menjadi sesuatu yang unik dalam dunia ekonomi dan sebaliknya bukti-bukti yang menentang akan semakin berkurang. Eugene Fama juga mengatakan bahwa pembuktian analisis teknikal ini sangat tipis dan inkonsisten yang merupakan "bentuk kekurangan" dari tehnik yang diterima secara umum yaitu Hipotesa Pasar Efisien. Analisis teknis ini lebih banyak digunakan para praktisi dibandingkan penggunaan analisis fundamental. Beberapa studi internal mengindikasikan 
bahwa aturan perdagangan tehnikal ini dapat menghasilkan imbal hasil yang konsisten pada periode hingga tahun 1987, kebanyakan penelitian akademis menitik beratkan pada sifat alamiah dari posisi anomaly dari pasar uang.

Metode dan Taktik. Menurut Neely,CJ (2001) Intervensi pasar valuta asing melibatkan upaya untuk mengubah nilai yang dipasarkan pelaku pasar pada mata uang tertentu. Cara melakukannya tidak segera jelas, terutama karena pasar valuta asing jauh dari homogeny. Perdagangan valuta asing berfrekuensi tinggi dan bertekanan tinggi oleh para professional pembuat pasar yang paling aktif dilaporkan. Dipasar ini, harga tampaknya dapat terganggu oleh berita-berita yang cukup tidak penting dengan sedikit bukti determinan fundamental yang bekerja untuk menetapkan nilai ekuilibrium. Bagi investor lintas batas wawasan investasi jangka menengah dan panjang,di sisi lain, tekanan pesanan langsung dan jangka pendek mengalir pada posisi terbuka pembuat pasar hamper tidak relevan. Yang penting adalah kemungkinan akumulasi aliran valuta asing atas investasi.

Studi tentang Teknik Candlestick. Nison (1991) memperkenalkan teknik candlestick ke dunia barat,teknik ini menjadi focus perhatian dan semakin banyak penelitian terkait baru-baru ini muncul. Caginalp dan Laurent (1998) mengumpulkan data candlestick harian untuk semua saham S \& P 500 selama periode 1992-1996 dan kemudian menggunakan delapan bola pembalikan tiga hari untuk mengujinya. Studi mereka menerapkan uji-Z untuk menguji kemampuan meramalkan perubahan tren dan menyimpulkan bahwa semua dari delapan pola pembalikan ini memiliki kekuatan prediktif yang baik. Dengan kata lain,teknik candlestick Jepang memiliki nilai bagi investor. Fock,Klein, dan Zewergel (2005) menggunakan data candlestick intraday selama lima menit dari DAX berjangka pada indeks saham Jerman DAX (FDAX) dan obligasi berjangka pada obligasi pemerintah Jerman (FGBL) selama periode 2002-2003. Mereka menerepkan t-test untuk menguji candlestick terhadap patokan yang dibangun dari sinyal beli acak di futures yang mendasari dan menemukan candlestick tidak biasa mendapatkan pengembalian abnormal. Marshall, Young, dan Cahan (2006) menggunakan pendekatan yang sama untuk menguji kekuatan prediksi strategi perdagangan candlestick di pasar Jepang. Mereka memilih 100 saham terbesar yang terdaftar di Bursa Saham Tokyo selama periode 1975-2004 di pasar Jepang karena ini adalah pasar ekuitas terbesar kedua di dunia dan juga tempat dimana teknik lilin awalnya dikembangkan. Hasil mereka sama seperti sebelumnya dalam strategi perdagangan candlestick yang dianggap tidak berguna dalam hal memungkinkan investor memprediksi tren harga di masa depan.

Perincian Produk dan Spesifikasi Kontrak Produk yang diperdagangkan oleh Perusahaan PT.Victory International Futures. Tabel 1 menyajikan spesifikasi atas kontrak forex dan gold 


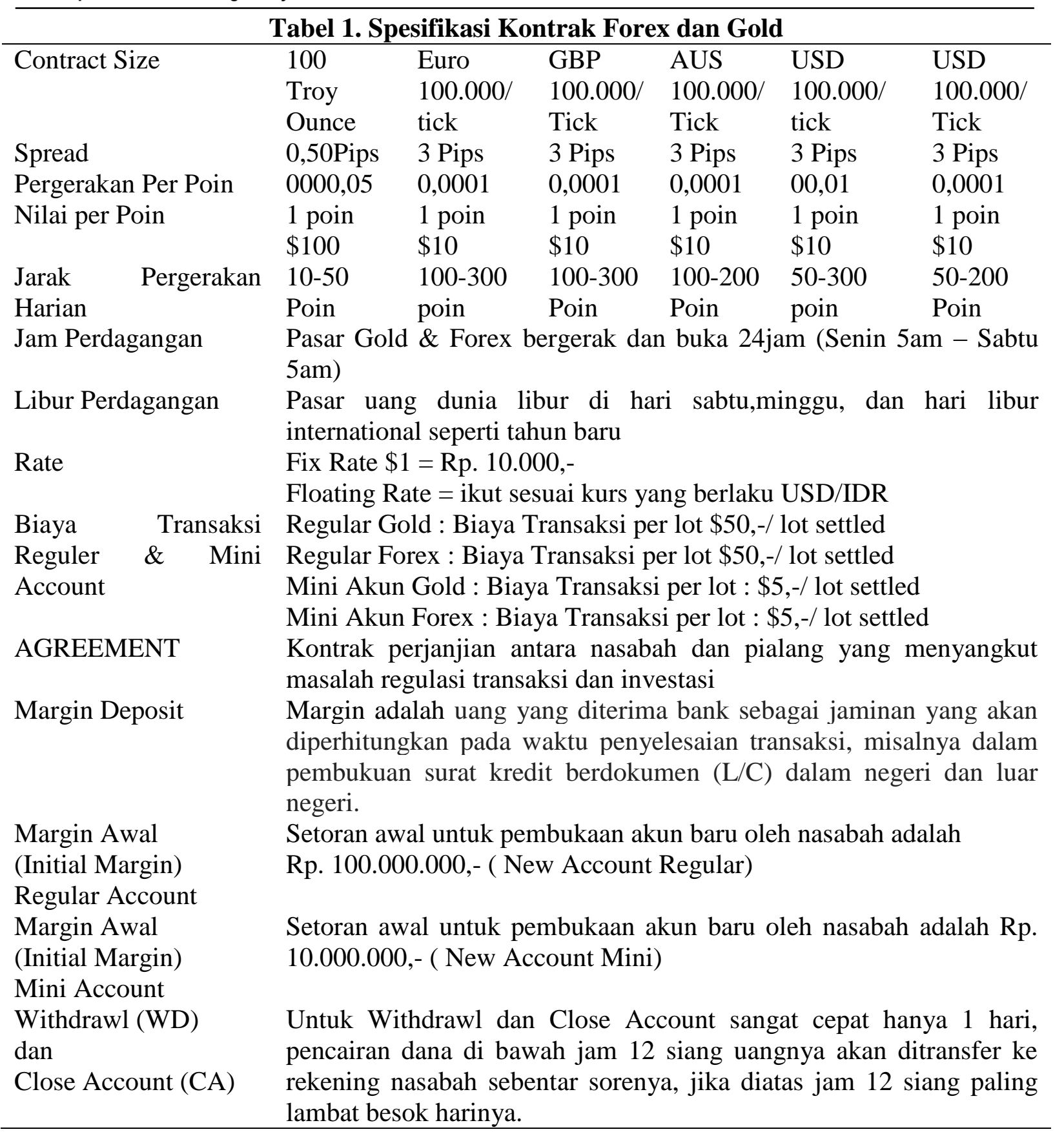

\section{METODE DAN TEKNIK PENERAPAN IPTEKS}

\subsection{Metode Penerapan Ipteks}

Metode penerapan ipteks yang diterapkan adalah Implementasi Cost dan Ekuitas (Equity). Sesuai dengan definisi investasi menurut PSAK No.13 adalah salah suatu sarana untuk menumbuhkan kekayaan melalui penerimaan hasil investasi (dividen) dan melalui apresiasi nilai yang diperoleh akibat kepemilikan saham perusahaan.

\subsection{Teknik Penerapan Ipteks}

Teknis penerapan ipteks yang diterapkan adalah untuk menganalisis pasar menggunakan Technical Analysis dan Fundamental Analysis. 


\section{PEMBAHASAN}

\subsection{Gambaran Objek Penerapan Ipteks}

Dengan fokus utama pada Forex,berjangka indeks,komoditi dan CFD,kami berkomitmen untuk memenuhi kebutuhan klien kami,membantu mereka untuk membuat keputusan cerdas dan memberdayakan mereka untuk menjadi pedagang yang sukses dan investor di pasar ekonomi. Perusahaan kami ini mengoperasikan perkiraan jam dan bertujuan untuk menyediakan real-time broker dan layanan investor dipasar-pasar utama di seluruh dunia. Didirikan pada tahun 2003, PT.Victory International Futures telah diperluas diseluruh kelas asset multi dan geografis catering klien,baik local maupun international. Kesuksesan kami didasarkan pada kami eksekusi perdagangan yang cepat dan akurat, riset pasar kekuatan dan layanan pribadi yang luar biasa dan dukungan, PT.Victory International Futures berkantor pusat di Surabaya kota yang telah menjadi pusat dari bisnis perdagangan dan industry di Indonesia. PT.Victory International Futures membantu klien dapat memiliki akses ke pasar ekonomi melalui operasi kami yang luas, berbagai macam platform perdagangan terbaik lewat elektronik dan bantuan jaringan yang kuat dari kelompok di perusahaan induk kami.

\subsection{Pembahasan}

Technical Analysis. Analisis Teknis atau lebih dikenal dengan istilah analisis teknikal adalah suatu teknik analisis yang dikenal dalam dunia keuangan yang digunakan untuk memprediksi trend suatu harga saham dengan cara mempelajari data pasar yang lampau,terutama pergerakan harga dan volume. Analisis teknikal dapat menggunakan berbagai model dan dasar misalnya,untuk pergerakan harga digunakan metode seperti misalnya Indeks Kekuatan Relatif, Indeks pergerakan rata-rata,regresi,korelasi antar pasar dan intra pasar,siklus ataupun dengan cara klasik yaitu menganalisi pola grafik. Analisis teknikal dikenal secara luas di antara para pedagang saham (atau dikenal dengan sebutan "trader") dan para professional dibidang keungan, namun dalam dunia akademis dianggan sebagain pseudosains or "voodoo finance;" it receives little or no direct support from academic sources and is considered akin to "astrology." Dalam pasar valuta asing, analisis teknis ini lebih banyak digunakan para praktisi dibandingkan penggunaan analisis fundamental. Banyak cara pembelajaran analisis teknikal. Para penganut cara pembelajaran dari teknik yang berbeda-beda (misalnya grafik lilin atas lebih dikenal luas dengan istilah candlestick chart,Teori Dow, dan Teori Elliot wave seringkali mengabaikan teknik pendekatan lainnya, namun banyak pula yang mengkombinasikan beberapa elemen pembelajaran. Analisis ini berupaya untuk mengidentifikasi patron harga dan tren dalam pasar keuangan dan berupaya untuk mengeksploitasi patron tersebut. Dalam penggunaan berbagai metode atau teknik maka mereka mengutamakan studi atas grafik harga. Para analis berupaya menemukan prototype patron seperti misalnya patron pembalikan yang sudah amat dikenal dengan istilah inggris head and shoulders (patron berbentuk seperti kepala dan bahu),serta mempelajari pulai berbagai patron seperti harga,volume, dan pergerakan rata-rata dari harga. Beberapa analis teknikal juga menggunakan indicator psikologis dari investor sentiment pasar. Analisis teknikal seringkali kontrak dengan analisis fundamental yaitu studi atas factor ekonomi yang diyakini beberapa analis mampu memengaruhi harga dalam pasar keuangan. Para analis teknikal meyakini bahwa harga tersebut sudah mencerminkan semua pengaruh ekonomi tersebut sebelum investor menyadarinya. Beberapa pedagang menggunakan salah satu dari teknikal atau fundamental secara eksklusif namun beberapa lainnya menggabungkan keduanya dalam melakukan analisis.

Fundamental Analysis. Analisis Fundamental adalah metode analisis yang didasarkan pada fundamental ekonomi suatu perusahaan. Teknis ini menitik beratkan pada rasio finansial dan kejadian - kejadian yang secara langsung maupun tidak langsung memengaruhi kinerja keuangan perusahaan. Sebagian pakar berpendapat teknik analisis fundamental lebih cocok untuk membuat keputusan dalam memilih saham perusahaan mana 
yang dibeli untuk jangka panjang. Analisis fundamental dibagi dalam tiga tahapan analisis (1) Analisis Ekonomi (2) Analisis Industri (3) Analisis Perusahaan. Analisis Fundamental Perusahaan secara umum melibatkan banyak sekali data variable yang harus dianalisis,dimana beberapa diantara variable tersebut yang cukup penting untuk diperhatikan yaitu : pertumbuhan pendapatan (revenue growth), rasio laba terhadap saham yang beredar (earning per share-eps), rasio pertumbuhan eps, rasio harga saham terhadap laba perlembar saham (price earning ratio), rasio harga saham terhadap pertumbuhan laba perseroan (price earning growth ratio), rasio harga saham terhadap penjualan (price/sale ratio), rasio harga saham terhadap nilai buku (price book value), rasio hutang perseroan (debt rasio), dan margin keuntungan bersih (net profit margin). Analisis Fundamental untuk pasar uang memberi pengaruh kepada trend perubahan harga (arah dari harga suatu mata uang secara keseluruhan) yang lebih banyak dipengaruhi oleh kebijakan-kebijakan yang dilakukan pemerintahan (otoritas moneter) ataupun data-data yang dirilis oleh berbagai sumber maupun berita-berita tertentu yang belum pasti kebenaranya (market sentiment dan market rumors). Ada beberapa factor yang mempengaruhi Analisis Fundamental : Factor Politik, Factor Ekonomi, Factor Keuangan, dan Factor Eksternal. Jadi menurut standar akuntansi di sebagian besar Negara di dunia ini menggariskan bahwa penggunaan metode akuntansi untuk investasi saham tergantung pada tingkat kepemilikan da nada tidaknya pengaruh signifikan yang dimiliki oleh investor terhadap investee. Demikian pula halnya Indonesia. Melalui Dewan Standar Akuntasi Keuangan (DSAK), Ikatan Akuntan Indonesia, telah membuat standar pencatatan dan pelaporan untuk investasi saham melalui beberapa Pernyataan Standar, antara lain PSAK No. 7,13,15,22, dan 50.

\section{KESIMPULAN DAN SARAN}

\subsection{Kesimpulan}

Perusahaan sudah sangat aktif dalam melakukan investasi di dunia berjangka,perusahaan ini juga tidak termasuk perusahaan penipuan di bidang investasi.

\subsection{Saran}

Perlunya Perusahaan sebaiknya mengarahkan tradernya, broker, dan nasabahnya dengan memperhatikan money management guna mengantisipasi dan meminimalis kerugian dalam bertransksi forex.

\section{DAFTAR PUSTAKA}

Cross,S.Y (1998). All About the Foreign Exchange Market in the United States, Federal Reserve Bank of New York chapter 11, 113-115.

Eugene,F. (1970), "Efficient Capital Market: A Review of Theory and Empirical Work," The Journal of Finance, 25 (2): 383-417.

Frank,J.A. (1990). "Chartists, Fundamentalists, and Trading in the Foreign Exchange Market". The American Economic Review. 80(4):3-17.

Lo,A.W. (2000). Foundations of Technical Analysis: Computational Algorithms, Statistical Inference, and Empirical Implementation”. The Journal of Finance, 55(4),1705-1765.

Neely,C.J. (2001). "Technical analysis and Central Bank Intervention, Journal of International Money and Finance, 20(7), 949-70.

Nison,S (1991). Japanese Candlesticks: New Japanese Charting Techniques Revealed, John Wiley and Sons, 14.

Osler,K (2000). Support for Resistance: Technical Analysis and Intraday Exchange Rates, FRBNY Economic Polisy Review.

Paulos,J.A (2003). A Mathematician Plays the Stock Market. Basic Books 
Poser,Steven W. (2003). Applying Elliott Wave Theory Profitably, John Wiley and Sons, 71. PT.Victory International Futures Cabang Area Manado,Business Plan.

Sullivan, R. (1999). "Data-Snooping, Technical Trading Rule Performance, and the Bootstrap". The Journal of Finance. 54(5),1647-1691

Sebastian,E (2006). National Bureau of Economic Research.

Taylor, M.P., (1992). "The Use of Technical Analysis in the Foreign Exchange Market," Journal of International Money and Finance, 11(3),304-314. 